[Jpn. J. Sanit. Zool. Vol. 42 No. 1 p. 9-13 1991]

\title{
Records of the genus Lotophila Lioy from the Oriental region, with the description of a new subspecies of $L$. pallida Hayashi (Diptera, Sphaeroceridae) $^{*, * *}$
}

\author{
Toshihiko HaYas HI ${ }^{* * *}$ \\ Department of Medical Zoology, Saitama Medical School, \\ Moroyama-machi, Iruma-gun, Saitama 350-04, Japan
}

(Received: July 16, 1990)

Key words: Lotophila, Oriental region, Sphaeroceridae, Diptera.

Abstract : Three species of the genus Lotophila Lioy and a new subspecies of L. pallida Hayashi, 1985, are recorded from the Oriental region.

Up to the present, the genus Lotophila Lioy consists of 5 species: L. atra (Meigen, 1830); L. bicolor Norrbom et Marshall, 1988 ; L. confusa Norrbom et Marshall, 1988; L. norrbomi (Papp, 1988); and L. pallida Hayashi, 1985. Of these, 3 species, L. atra, $L$. bicolor and $L$. norrbomi, are recorded from the Oriental region. $L$. bicolor and $L$. norrbomi are known only from the Oriental region and were described basing on only a few specimens. $L$. atra is distributed widely in the Holarctic region, but in the Oriental region only 3 specimens have been known from the northern part of Pakistan (Papp, 1988).

I had a chance to examine Oriental materials of the genus and found all the 3 species hitherto recorded among them, so I give here additional data of these 3 species. Besides these, I describe in this paper a new

* Results of Kyushu University Scientific Expedition to the Nepal Himalaya, Diptera 11.

** This study was partly supported by the Grantin-Aid for Monbusho International Scientific Research Program (Field Research) to the Toyama Medical and Pharmaceutical University in 1986, 1987 and 1988 (Grant Nos. 61042004,62041036 and 63041058). ZDSA Series No. 19.

*** 林 利彦: 埼玉医科大学医動物学教室（干350-04 埼玉県入間郡毛呂山町毛呂本郷 38) subspecies of $L$. pallida new to the region. It is different from the typical form from Japan in male genitalia.

Specimens used in this study are based on the sphaerocerid fly collection made by Kyushu University Scientific Expedition to the Nepal Himalaya in 1971-1972 and the expedition to Pakistan supported by the Grant-in-Aid for Monbusho International Scientific Research Program.

\section{Lotophila atra (Meigen, 1830)}

Borborus ater Meigen, 1830, Syst. Beschr. bekannt. europ. zweiflug. Insekt., Band G. Schulzische. Buchhandlung. Hamm., 6: 203.

Specimens examined. PAKISTAN: $2 \hat{o} \hat{o}$, $2 \%$, Murree, Punjab Prov., 18 vii, 1987, K. Kanmiya; 16 of $\delta, 8$ 우 $\circ$, ditto, 21 vii, 1988, $\mathrm{T}$. Hayashi; $17 \hat{\delta} \delta, 11 \%$, Ayubia, NWFP, 22 vii, 1988, T. Hayashi; 8소 $\hat{o}, 6 \% q$, ditto, 25 vii, 1988, T. Hayashi; $2 \hat{o} \hat{o}, 1$ \% , ditto, 26 vii, 1988, T. Hayashi; $12 \delta \hat{\delta}, 15 \% q$, Nathiagali, NWFP, 27 vii, 1988, T. Hayashi; $18 \hat{o} \hat{o}$, 11 우, ditto, 28 vii, 1988, T. Hayashi; $3 \hat{o} \hat{o}$, ditto, 29 vii, 1988, T. Hayashi; $156 \hat{\text { ô }} \hat{o}$, 125 우, Tandani, NWFP, 1 viii, 1988, T. Hayashi; $6 \hat{\text { oे }}$ ô, 4 ㅇ 9 , Naltar, NWFP, 28 vii, 1987, K. Kanmiya.

Distribution. Europe, Soviet Union, Af- 

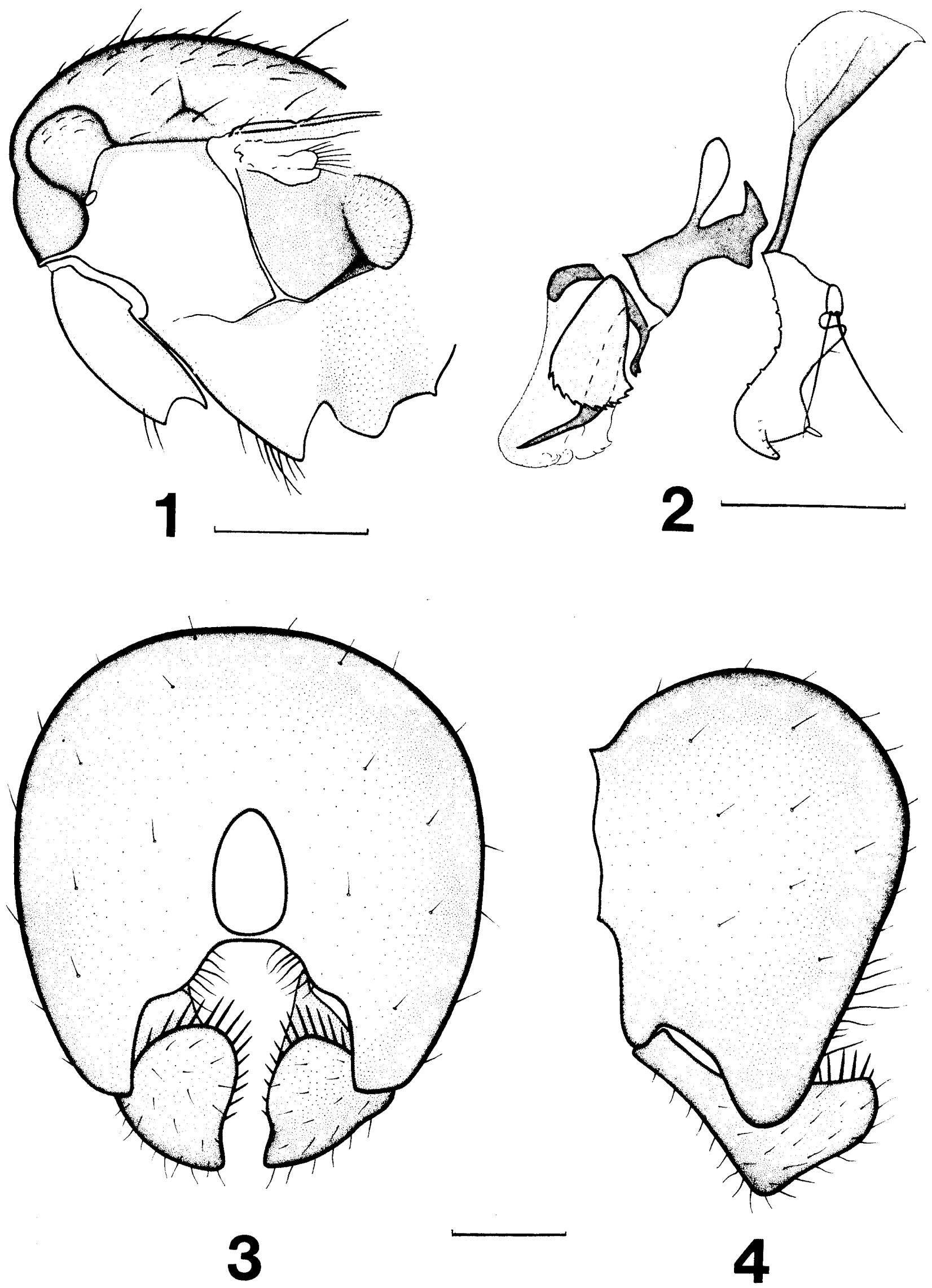

Figs. 1-4 Lotophila bicolor Norrbom et Marshall.

1: thorax, lateral view. Scale: $0.5 \mathrm{~mm}$. 2: aedeagus and associated parts, lateral view. Scale: $0.2 \mathrm{~mm}$. 3: male terminalia, caudal view. 4 : ditto, lateral view. Scale: $0.2 \mathrm{~mm}$. 
ghanistan, Pakistan, Mongolia, China, Japan and North America.

Remarks. Papp (1988) first recorded this species from Pakistan. I captured all individuals in the mountainous areas over the elevation of $2,200 \mathrm{~m}$ in the northern part of Pakistan, where the Palaearctic species were commonly found. It is widely distributed in the Holarctic region.

Adults are found on cattle dung abundantly, and a few individuals were captured also on human excrement.

\section{Lotophila bicolor Norrbom et Marshall, 1988 (Figs. 1-4)}

Lotophila bicolor Norrbom et Marshall, 1988, Proc. Entomol. Soc. Ont., 119: 28.

Specimens examined. NEPAL: $1 \hat{\sigma}$, Dobang Kharka, $2,400 \mathrm{~m}, 28^{\circ} 24^{\prime} \mathrm{N}, 83^{\circ} 24^{\prime} \mathrm{E}$, 19-20 x, 1971, A. Nakanishi, Malaise trap; 1 \% , Topke Gola, $3,700 \mathrm{~m}, 27^{\circ} 38^{\prime} \mathrm{N}, 87^{\circ} 35^{\prime} \mathrm{E}-$ Thurukpa, $2,600 \mathrm{~m}, 27^{\circ} 36^{\prime} \mathrm{N}, 87^{\circ} 36^{\prime} \mathrm{E}, 9$ vii, 1972, Pemba Norbu.

Distribution. Nepal.

Remarks. Though Norrbom and Marshall (1988) did not mention the criteria, this species is easily distinguishable by the strong $1+2 d c$ (Fig. 1). Microtrichial pattern of anepisternum, yellowish legs and male genitalia are also characteristic (Figs. 1-4).

$L$. bicolor is one of little known species and was described based on only 3 male specimens, and known only from Nepal. The female of this species is recorded here for the first time.

\section{Lotophila norrbomi (Papp, 1988)}

Copromyza norrbomi Papp, 1988, Revue suisse zool., 95: 467.

Specimen examined. NEPAL: $1 \%$, Dobang Kharka, $2,400 \mathrm{~m}, 28^{\circ} 36^{\prime} \mathrm{N}, 83^{\circ} 24^{\prime} \mathrm{E}$, 20-22 x, 1971, A. Nakanishi, Malaise Trap.

Distribution. India and Nepal.

\section{Lotophila pallida nepalensis n. 8sp.} (Figs. 5-7)

The specimens examined here are similar to those of $L$. pallida from Japan externally except for weakened setae, especially in interfrontal setae and additional ones on orbit.
But there are several distinct differences in male genitalia: Surstylus (Fig. 5) slenderer and longer; distiphallus (Fig. 7) less sclerotized; paramere (Fig. 6) more rounded and strongly curved apically.

Holotype. of, NEPAL: Dobang Kharka, $2,400 \mathrm{~m}, 28^{\circ} 36^{\prime} \mathrm{N}, 83^{\circ} 24^{\prime} \mathrm{E}, 23 \mathrm{x}, 1971$, A. Nakanishi.

Paratypes. NEPAL: $1 \hat{\imath}$, Basantapur, $2,300 \mathrm{~m}, 27^{\circ} 06^{\prime} \mathrm{N}, 87^{\circ} 23^{\prime} \mathrm{E}-27^{\circ} 08^{\prime} \mathrm{N}, 87^{\circ} 26^{\prime} \mathrm{E}$, 15 vi, 1972, H. Makihara; 1\%, Dobang Kharka, $2,400 \mathrm{~m}, 28^{\circ} 36^{\prime} \mathrm{N}, 83^{\circ} 24^{\prime} \mathrm{E}, 28 \mathrm{x}$, 1971, A. Nakanishi.

The holotype and 1 \& paratype are in the Biological Laboratory, College of General Education, Kyushu University, Fukuoka. One of paratype is in the author's collection.

Distribution. Nepal.

Remarks. The new subspecies is clearly distinguished from the nominal subspecies by the shape of paramere (Figs. 6 and 9). $L$. pallida was formerly recorded only from Japan (Hayashi, 1985; Norrbom and Marshall, 1988). This is the first record from Nepal and the Oriental region. These records suggest that the distribution of $L$. pallida is widespread in Asia.

\section{Agknowledgements}

I express my sincere thanks to Dr. K. Kamimura of Toyama Medical and Pharmaceutical University for giving me the opportunity to survey the sphaerocerid fauna of Pakistan, to Dr. H. Shima of Kyushu University for giving me the opportunity to examine the materials collected in Kyushu University Scientific Expedition to the Nepal Himalaya and to Dr. K. Kanmiya of Kurume University for giving me materials. I would like to thank Prof. E. Hori of Saitama Medical School for his kind encouragement and reading the manuscript. Thanks are also due to Dr. S. Shinonaga of Tokyo Medical and Dental University for reading the manuscript.

\section{REFERENCES}

Hayashi, T. (1985): Notes on Lotophila Lioy (Diptera, Sphaeroceridae) from Japan, with a description of a new species. Konty $\hat{u}, 53$ : 561564.

Norrbom, A. L. and S. A. Marshall (1988): New species and phylogenetic analysis of Lotophila Lioy (Diptera: Sphaeroceridae). Proc. Entomol. Soc. Ont., 119: 17-33. 

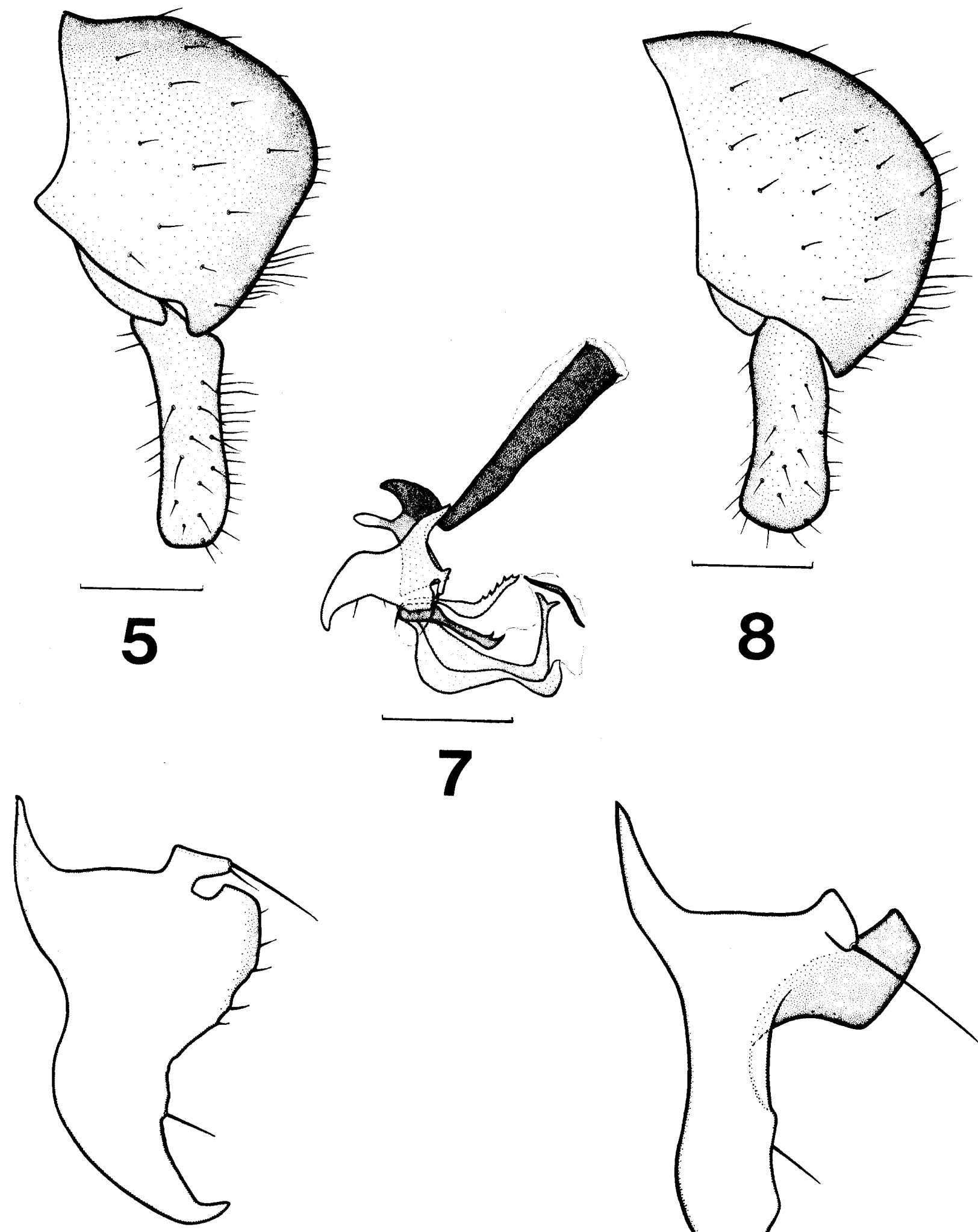

6

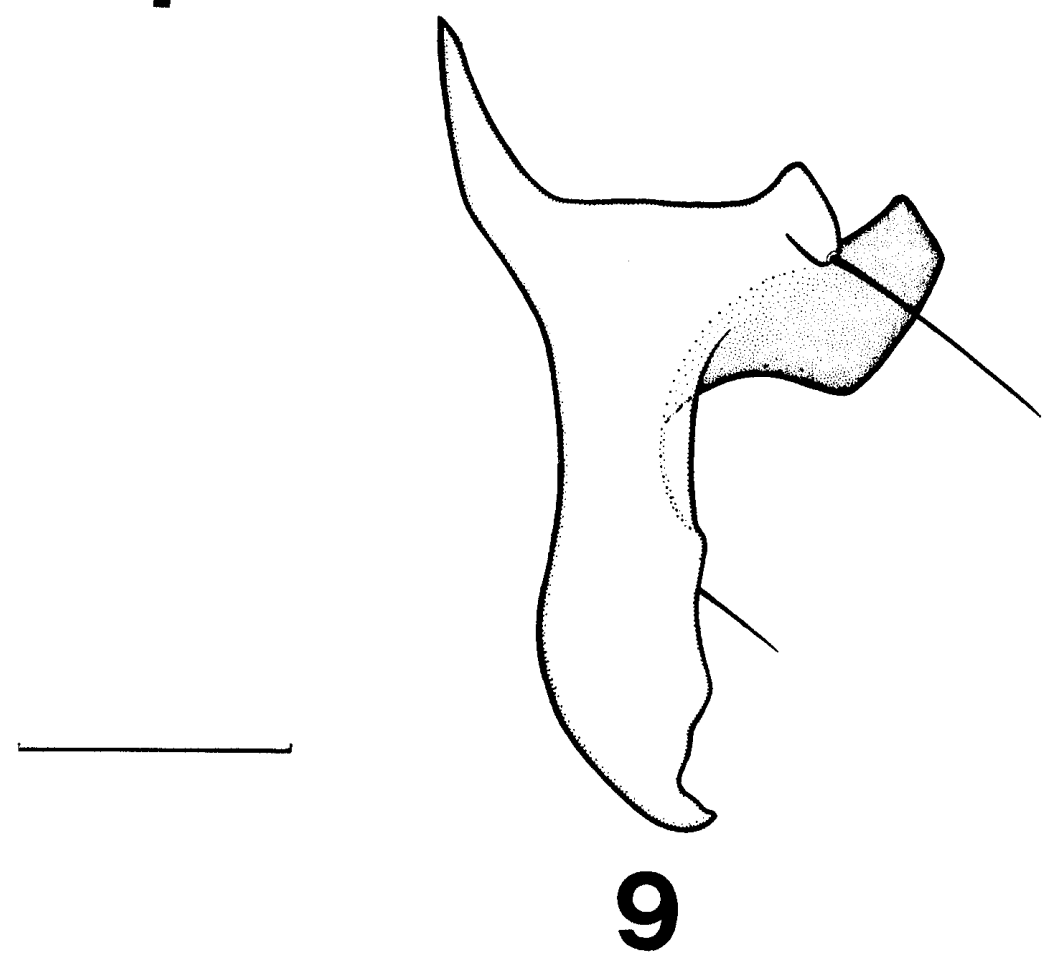

Figs. 5-9 
Papp, L. (1988): Sphaerocerinae and Copromyzinae (Sphaeroceridae, Diptera) from the Oriental region. Rev. Suisse Zool., 95: 461-469.

\section{摘要}

東洋区産トゲナシハヤトビバエ属の記録

（双翅目，ハヤトビバエ科）

東洋区においてはこれまで，トゲナシハヤトビバエ 属は 3 種, Lotophila atra (Meigen, 1830), L. bicolor Norrbom et Marshall, 1988, L. norrbomi
(Papp，1988） が記録されているが，いずれも数個体 のみで報告されている。著者は九州大学山岳会ネパー ルヒマラヤ学術調查隊（1971～1972）および文部省海 外学術調查によるパキスタンの探集品を調べた結果, 既知 3 種のトゲナシハヤトビバエと東洋区新記録のウ スイロトゲナシハヤトビバェ L. pallida Hayashi, 1985を見いだした。このネパール産のウスイロトゲナ シハヤトビバエは基産地である日本産のものと比べ, 雄生殖器, とくに paramere の形態に明らかな差異 があり，亜種と認め，L. pallida nepalensis n. ssp. として記載した.

Figs. 5-7 Lotophila pallida nepalensis n. ssp. 5: male terminalia, lateral view. Scale: $0.2 \mathrm{~mm}$. 6: paramere. Scale: $0.1 \mathrm{~mm}$. 7 : aedeagus and associated parts, lateral view. Scale: $0.2 \mathrm{~mm}$.

Figs. 8-9 Lotophila pallida pallida (Japan).

8: male terminalia, lateral view. Scale: $0.2 \mathrm{~mm}$. 9: paramere. Scale: $0.1 \mathrm{~mm}$. 